(C) Middle East Institute. This article is for personal research only and may not be copied or distributed in any form without the permission of The Middle East Journal.

\title{
The Political, Cultural, and Military Re-Awakening of the Kurdish Nationalist Movement in Iran
}

\section{Hashem Ahmadzadeh and Gareth Stansfield}

This article aims to shed light on the modern history of the Kurds in Iran, with particular reference made to the main Kurdish political and social movements of the 20 $0^{\text {th }}$ century following World War I and the establishment of an Iranian nation-state. The modernization and centralization of the new state deprived the non-Persian ethnic groups, including the Kurds, of democratically expressing their national aspirations. The consequences of this policy and the struggle of the Kurds against it throughout the remainder of the century and up to the present are the main issues discussed in this article.

$\mathbf{K}$ exemplified by the steadily increasing numbers of books on the subject, articles appearing in major global newspapers, and the international community's clearly greater awareness of the existence of a set of Kurdish issues that need to be addressed. However, a review of materials on the Kurds suggests that interest in Kurdish affairs tends to be heavily skewed, with the Kurds of Iraq and Turkey receiving the most attention as compared to analyses that focus upon the status of the Kurds in Iran or Syria.

It is to the Kurds of Iran that we turn our attention in this article. From being the intellectual center of the Kurdish nationalist movement in the mid- $20^{\text {th }}$ century, the Kurds of Iran slipped from the gaze of international observers as the Iranian state began to project its power more effectively across its territory following the end of World War II. Following the Islamic Revolution of 1979, the attention paid to Iran's Kurds has become largely negligible save for a small number of academic works and the occasional filing of copy from intrepid journalists. ${ }^{1}$ It is now of critical importance, however, for attention to be paid to the situation of the Kurds of Iran due to the heightened prominence of the Kurds in Middle East politics in general, and of Iranian affairs in particular.

Hashem Ahmadzadeh is Senior Lecturer in Kurdish Studies and Director of the Centre for Kurdish Studies at the University of Exeter. He has published widely on Kurdish literature, language, and politics. He is the author of Nation and Novel: A Study of the Persian and Kurdish Narrative Discourse, published by the University of Uppsala in 2003. A new print of the book was published by VDM Verlag in 2009. Gareth Stansfield is Professor of Middle East Politics and Director of the Institute of Arab and Islamic Studies at the University of Exeter. He is also an Associate Fellow of the Middle East and North Africa Programme at Chatham House. His most recent publications include Crisis in Kirkuk: The Ethnopolitics of Conflict and Compromise (with Liam Anderson, University of Pennsylvania Press, 2009) and Iraq: People, History, Politics (Polity Press, 2007). He wishes to thank The Leverhulme Trust for support provided by a Research Leadership Award to develop a program on "Ethnopolitics in a Globalized World," which facilitated his researching of this article.

1. Among the few academic works about the Kurds in general, including one or two chapters on Iranian Kurds, one can refer to two major works: one is Wadie Jwaideh's PhD dissertation, The Kurdish National Movement: Its Origins and Development, in 1960. The book was published in 2006 by Syracuse University Press. The other is Gerard Chaliand's edited book, People Without a Country: The Kurds and Kurdistan, which was published in 1980. 
The ambition of successive Iranian authorities to establish a nation-state that aimed to assimilate the non-Persian ethnic groups into a wider Iranian narrative has been largely unsuccessful and it is this failure of the Iranian national project and the resilience of a Kurdish agenda that is the focus of this article. In it, we attempt to shed light on the Kurdish experience in Iran since the formation of the modern state in the 1920s, with a focus on the last three decades that followed the Islamic Revolution of 1979.

\section{THE KURDS AND THE FORMATION OF THE IRANIAN NATION-STATE}

Faced with the threat posed by industrializing European states, both Qajar Iran and the Ottoman Empire pursued a policy of extensive modernization throughout the second half of the $19^{\text {th }}$ century. A key element of this policy was to promote the centralization of authority and administrative organization at the expense of the autonomy built up by groups living in provincial areas. As a result, the semi-independent Kurdish emirates were practically eliminated as meaning-

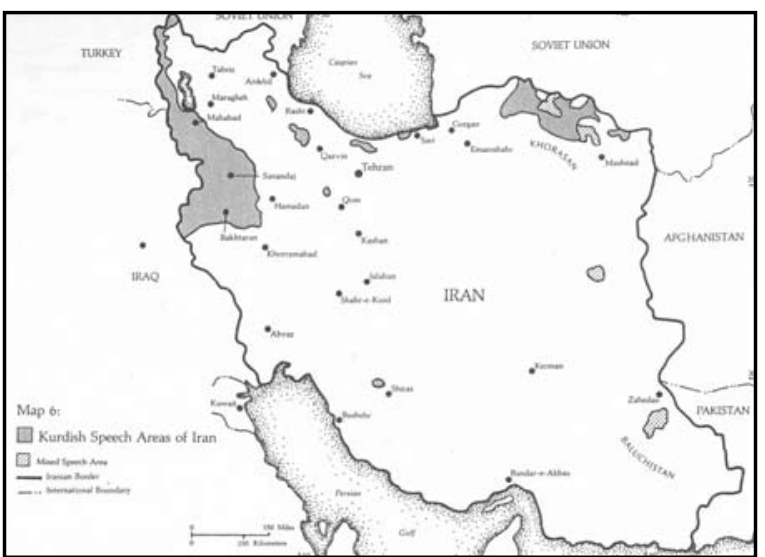

Map originally appeared in Amir Hassanpour, Nationalism and Language in Kurdistan, 1918-1985 (San Francisco: Mellen Research University Press, 1992), p. 9, and is used with permission from the author.

ful entities. However, the Ottoman and Qajar central governments were still far from strong enough to exercise control over vast territories. In Iran, the dominant feudal social structure was manifest in the form of local tribal leadership which governed areas deemed to be within their geographic sphere of control. ${ }^{2}$ Iranian Kurdistan, especially in its northern parts, was strongly characterized by this form of governance.

This political structure proved to be an enduring feature of the Iranian political scene - and one that is largely overlooked by many historians focusing on the early years of the Iranian state. Indeed, even the Iranian Constitutional Revolution of 1906-11, despite its significant achievements, failed to establish a democratic political system in Iran inclusive of these largely tribal regions; moreover, the years following World War I in Iran were characterized by a degree of anarchy in the government which facilitated the consolidation of Kurdish tribal authority. Alongside the domestic reasons which underlay this anarchy was the interference of foreign powers, namely Britain and Russia, which essentially had divided Iran between them. One effect of this imperial meddling was the rise of Iranian nationalism and an opportunity for a strong leader to take advantage of the chaotic political situation. This leader was Reza Shah, who emerged as Minister of War in 1921 and became King in 1925. Under Reza Shah, the state moved to reconsolidate its diffused authority by embarking upon a policy of centralization, bringing the Kurdish

2. Among the other ethnic groups with strong tribal relations, one can name the Baluchs, Bakhtiyaies, Qashqayees, Turkmens, significant Azari tribes in Azerbaijan, and Arabs in Khuzestan. 
feudal and tribal leaders into direct confrontation with the government.

Among the tribal Kurdish leaders, the head of the Shikak tribe, Ismail Agha Simko, proved to be the main opponent of Reza Shah's centralizing policies. By all accounts, Simko was successful in uniting a number of tribal leaders in the Kurdish areas against the central government, yet his ends are unclear, as there is little evidence to suggest that Simko's motives were driven by any particular Kurdish nationalist vision. David McDowall rightly asserts, "Simqu's [Simko's] revolt remained fatally handicapped by the nature of tribal politics." ${ }^{3}$ Lacking any clear nationalist vision and program and without any meaningful strength engendered by societal solidarity, Simko desperately sought alliances with the various local and regional powers in order to promote his own parochial initiatives. ${ }^{4}$ While in the beginning of his revolt he had been successful in cooperating with some Kurdish tribal leaders inside the Ottoman Empire, such as Shaykh Taha, and for a while drew the attention of Shaykh Mahmud Hafid in Iraqi Kurdistan, where he had established a short-lived Kurdish administration, he had on other occasions relied on Turkish authorities to conduct his resistance against the Iranian government - even though the same authorities were targeting Kurds within their own boundaries. After years of fighting against Reza Shah, Simko was invited to Ushnaviya by the Iranians, ostensibly to be pardoned and offered the governorship of the city. Unfortunately for Simko, the Iranian authorities had no intention of accommodating this increasingly powerful figure. The invitation proved to be part of a trap, and Simko was assassinated in 1930.

The motivations of Simko and the raison d'être of his revolt remain disputed. While some Kurds admire him for the bravery he showed in his resistance to Reza Shah, his opponents accuse him of being a cruel leader who threatened the territorial integrity of Iran and its legitimate modernizing ambitions. ${ }^{5}$ It seems clear that Simko lacked any nationalist agenda and his resistance was inspired mainly by his tribal ambitions and only partly by his ethnic and nationalist consciousness. Even so, despite the fact that Simko's revolt lacked an intellectual nationalist discourse, it provided the foundations of the Kurdish nationalist movement in Iran. Yet it arose not from any dialogue among Kurdish intellectuals in Iran, but rather as a reaction to the homogenizing Persian-first policy of Reza Shah, who wanted to build a nation based on the cultural and linguistic features of the Persians as the dominant ethnic group.

3. David McDowall, A Modern History of the Kurds (London: I.B. Tauris, 2005), p. 219.

4. Simko, being aware of his ethnic identity, aimed to have his own area under his control. The ongoing political instability in the region encouraged him to aim for relations with political actors in areas outside Iran's borders, e.g., areas under Sheikh Mahmud's control in today's Iraqi Kurdistan. The Turkish authorities, fighting against foreign, and especially British, forces in the area, aimed to use Simko against their enemies

5. Alireza Nazmi Afshar, the head of the "Diplomatic Commission of Western Azarbaydjan," refers to Simko as a murderer and bandit. See www.renesans.info/articles.php?id=1603. For Madani, a member of the KDPI's central committee, Simko had strong nationalist thoughts. Hussein Madani, Kurdistan u stratejiy dewletan [Kurdistan and the Strategy of the States], Vol. 2 (Stockholm: Spartryck, 2001), p. 72. Muhammad Rasul Hawar in his book, Smiko u bzutnaway natawayatiy kurd [Simko and the Kurdish Nationalist Movement] writes exclusively to introduce Simko as a nationalist hero who devoted his life to his country and people. For a detailed analytical account of Simko see Martin van Bruinessen, "Kurdish tribes and the State of Iran: the case of Simko's revolt," in Richard Tapper, ed., The Conflict of Tribe and State in Iran and Afghanistan (London: Croom Helm, 1983). 


\section{WORLD WAR II AND THE EMERGENCE OF A MODERN KURDISH NATIONALIST DISCOURSE}

Reza Shah was successful in defeating the local and regional rebellions, and by the late 1930s his policy of promoting social and cultural homogeneity and centralized authority was well underway. However, the start of World War II had profound implications for Iran and the Kurds. Iran was occupied by British and Soviet forces due to Reza Shah's perceived sympathy for the Axis — effectively changing the political space in Iran and halting the progress of Reza Shah's policies. Following his abdication in 1941, Iranian Kurdistan - even though it was occupied by Soviet troops - experienced a power vacuum, as the once powerful tribes struggled to fill the void. Instead, the social and economic policies pursued by Reza Shah had profoundly influenced the character of Iranian Kurdish society, with a new middle class forming and an urban educated stratum now apparent. It was actors from within this new urban class that took advantage of the power vacuum. A new, modern organization called Komalay Jiyanaway Kurd/Kurdistan (The Society for the Revival of the Kurds/Kurdistan) was established in September 1942 in Mahabad. The organization, commonly referred to as $\mathrm{JK},{ }^{6}$ soon became popular and less than one year after its establishment started publishing a journal called Nishtiman (Motherland). ${ }^{7}$ The articles in Nishtiman illustrated that the founders of JK were aware of their distinctive ethnicity. They also were motivated to develop a Kurdish homeland that encompassed not only Iranian Kurdistan, but was also inclusive of the Kurdish regions of Turkey and Iraq. However, the development of JK was curtailed by the social limits of a Kurdish society still heavily colored, if not dominated, by tribal traditions. These social and cultural limitations combined with the interfering policies of the Soviet occupiers and resulted in the eclipsing of the JK by the Kurdistan Democratic Party (KDP) in September $1945 .^{8}$ The KDP, under the leadership of Qazi Muhammad, declared the establishment of the Republic of Kurdistan on January 22, 1946 in Mahabad. The republic, except for the Soviet Union's practical support, was not recognized by any country. The areas under the Republic's control stretched from Urumiya to Saqiz; some of the major Kurdish cities, such as Sanandaj (Sine) and Kirmanshan, were outside the Republic's domain.

6. There are some disputes among scholars concerning the equivalent of the initials of JK. For a record of the various ideas on the name of the association see Hashem Ahmadzadeh, Nation and Novel: A Study of Persian and Kurdish Narrative Discourse (Uppsala: Uppsala University Press, 2003), pp. 148-49.

7. In the first issue of Nishtiman, the official journal of the JK, the creation of a greater Kurdistan was declared as the aim of the JK. See Nishtiman, Vol. 1, No. 1 (July 1943).

8. The established party was officially called the Kurdistan Democratic Party. According to Jalil Gadani, in the first conference of the party in 1955 the word Iran was added, following a dash, to the name of the Party for the first time. Jalil Gadani, Penja Sal Khabat: Kurte Mejuyaki Hizibi Demokrati Kurdistani Eran [Fifty Years of Struggle: A Short History of KDPI], Vol. 1 (Wazarati Roshanbiri haremi Kurdistan), p. 98. However, Abdullah Hassanzade argues that it was in the third conference in 1971 that for the first time "Iran" within a parentheses was added to the name of the party. In the fourth congress of the party in 1980 in Mahabad the parentheses also was omitted and the party was officially called KDPI (Democratic Party of Iranian Kurdistan). Abdullah Hassanzade, Niw Sada Tekoshan [Half a Century of Struggle] (Komisyoni chapamani hizbi demokrati Kurdistan, 1995), pp. 68-9. 
Due to internal disorganization and the weakening of international (Soviet) support following the end of the war, the Republic was defeated by the Iranian army in the middle of December 1946 and its leadership executed. Even so, although it lasted less than one year, the formation of the Kurdish Republic was a historical turning point in the realization of Kurdish nationalism.

\section{KURDISTAN IN THE AFTERMATH OF MAHABAD}

After the collapse of the Republic of Kurdistan, the Kurdish national movement in Iran experienced a long and hard period of recovery. The leading political force among the Kurds, the KDP, had lost its legendary leader Qazi Mohammad along with several other visionary figures. As Iranian Kurdistan was reoccupied by the Iranian army, the KDP was organizationally devastated to the extent that the KDP became reliant upon its relationship with the Tudeh Party in order to exist and even survive. ${ }^{9}$ But, by the mid-1950s, the KDP had again begun to reassert itself as a key actor. Following the coup of 1953 and the collapse of Muhammad Mossadeq's government, the new KDP leaders sought to reorganize the party. The party's first conference, which was held in 1955, was an important step towards this. Illustrating the resurgence of support for the KDP, the conference insisted on the independence of the party from other organizations, effectively severing its relations with the Tudeh. ${ }^{10}$

Recognizing the new threat posed by the reorganized KDP moving away from the Tudeh, the Iranian government strengthened its oppressive policy and made conditions for KDP members much more difficult. In 1959 the clandestine organizations of the Iranian KDP were discovered by the police following the arrest of Simayli Qassimlu, a KDP member. About 250 members of the KDP were arrested and many of the key figures of the party were given long prison sentences. ${ }^{11}$ Such events increased the number of Kurdish political activists who found a safe haven in Iraqi Kurdistan, following 'Abd al-Karim Qassim's coup d'état against the monarchy in 1958. Nonetheless, this safe haven could not last for long due to the war between the Iraqi regime and the Iraqi Kurds, as well as the reliance of Iraqi Kurdish leader Mustafa Barzani on the Iranian regime.

In the 1960s, the Iranian KDP's energies were focused mainly on deep internal conflicts between its various factions - a state of affairs that would last into the $21^{\text {st }}$ century. ${ }^{12}$ The divisions were so serious that the KDP as it was constituted could not

9. The relationship of the KDP and Tudeh has been so close that the KDP was practically the organization of the Tudeh in Kurdistan. Abd al-Rahman Qasimlu, Chil Sal Khabat la Penawi Azadi [Forty Years Struggle for the Sake of Freedom] (Komisyoni chapamani hizbi demokrati kwrdistani Eran, 2002), p. 104. Hassanzade, Niw Sada Tekoshan, p. 15. This decision was officially made in the first conference of the KDP in 1955. Hassanzade, Niw Sada Tekoshan, p. 16. Despite the official decision to cut the relations with the Tudeh Party in 1955, the influence of the Tudeh on the KDP lasted until the 1980s.

10. Gadani, Penja Sal Khabat: Kurte Mejuyaki Hizibi, p. 99.

11. Hassanzade, Niw Sada Tekoshan, p. 22.

12. During this period, the leader of the KDP, Ahmad Tofiq had a close relationship with Mustafa Barzani, the leader of the Iraqi KDP. Tofiq's interest in Barzani was reflected in one of the decisions of 
remain integrated, with the result being the formation of a new group that challenged the authority of the official leadership.

In 1967, a group of cadres who were against the policy of the pro-Barzani leader of the KDP, Ahmad Tofiq, founded a Revolutionary Committee that aimed to conduct an armed struggle against the Iranian regime. In its 18-month existence, the Revolutionary Committee succeeded in highlighting the situation of the Kurds and promoting a wider sense of Kurdish nationalism, while dealing locally significant military blows against the Iranian military. Yet, faced with immense odds, the movement was ultimately defeated and many of the KDP's most influential members were killed. ${ }^{13}$

The declaration of the Autonomy Law by the Iraqi government in March 1970 was warmly welcomed by the Iranian KDP authorities in Iraqi Kurdistan, who hoped that it would assist their struggle in Iranian Kurdistan. ${ }^{14}$ However, when a KDP delegation met Mustafa Barzani to both congratulate him on that historical achievement and to ask him for his support, they were disappointed to find that Barzani's policy concerning Iran had not changed and that the ban against the Iranian KDP's struggle against the Iranian government would remain intact. ${ }^{15}$ However, by this time the Iranian KDP had established contacts with the Iraqi regime, with the result being that the Kurds of Iraq and Iran would soon find themselves being used as proxies against each other. ${ }^{16}$

In June 1971 the third conference of the Iranian KDP was held in Koye in Iraqi Kurdistan. During this conference Dr. Abdul Rahman Qasimlu was elected as the General Secretary of the party, remaining in this post until he was assassinated in Vienna in

\section{[Continued from previous page]}

the second congress of the KDP in 1964 when Barzani was appointed the leader of the party. Hassanzade, pointing to this decision, evaluates it as a strange one, saying that Mustafa Barzani was in fact the leader of the Iraqi KDP. Hassanzade, Niw Sada Tekoshan, p. 41. During the early 1970s, Qasimlu's faction succeeded in isolating Tofiq and they practically gained the leadership of the KDP. During the third conference of the KDPI in 1971, some of the KDPI cadres under the leadership of Mala Sayid Rashid opposed the decisions against Ahmad Tofiq. These cadres first built up the Provisional Committee of the KDP. Later on they renamed their group the Komalay Yeksani (Egalitarian Organization). Gadani, Penja Sal Khabat: Kurte Mejuyaki Hizibi, p. 171. In the following summer Tofiq was arrested by the Iraqi government and was soon eliminated suspiciously. The animosity between Qasimlu and Tofiq was so harsh that Tofiq's name was practically omitted from the official historiography of the KDP. During recent years some Kurdish activists both within and outside the KDP have started to revise the official approach to Tofiq's role in the KDP. For a detailed and sympathetic account of Tofiq's life and ideas, see Dr. Yasin Sardashti, Zhiyan u Tekoshani Siyasiy Ahmad Tofiq (1931-1973) [The Life and Political Struggle of Ahmad Tofiq, 1931-1973] (Shivan, Silemani, 2007).

13. Hassanzade, Niw Sada Tekoshan, p. 48.

14. The Autonomy Law of 1970 was an event of great importance in the relations between the Iraqi government and the Iraqi Kurds. For the first time it recognized the rights of the Iraqi Kurds and their control over the country's mainly Kurdish areas, except for Kirkuk, which was left for future negotiations. It was the failure of these negotiations that resulted in the resumption of the war between the Kurds and the Iraqi government. The Kurdish movement in Iraq finally was defeated in March 1975 when the Iranian regime withdrew its support of the Kurds. The Iraqi Kurdish rebellion would then remain in abeyance until Saddam's defeat in 1991 following the invasion of Kuwait.

15. Hassanzade, Niw Sada Tekoshan, p. 59.

16. After Dr. Qasimlu's return to Iraq from Europe and after building up a new central committee in 1970, the KDP officially contacted the Iraqi Ba'th Party and consequently they signed a mutual cooperation agreement. Hassanzade, Niw Sada Tekoshan, p. 64. 
1989 by security operatives of the Islamic Republic of Iran.

To exist as proxies in the struggle between Iraq and Iran was not, however, a sustainable situation and would fall victim to changes in the relationship between Baghdad and Tehran. On March 6, 1975, an agreement between Iraq and Iran was signed in Algeria. Based on this agreement the Iranian regime stopped its support of the Iraqi Kurds, with Iraq then ceding control of the Shatt al-Arab to Iran. As a result of this agreement, Kurdish resistance against Iraq evaporated overnight and, by the middle of March, the Kurdish fighters either surrendered to the Iraqi army or took refuge in Iran. In turn, the Iraqi regime restricted the activities of the Iranian KDP in Iraq and forbade the party to publish its journal, Kurdistan, in Iraq.

Towards the end of the 1970s, the Iranian regime was facing serious domestic political unrest. In the middle of the autumn of 1978, a committee named Zagros was organized by the KDP in order to send its leading members to Iran to contribute to the struggle of the people against the Iranian regime. Thus, alongside the Iranian people, the Iranian Kurds showed their active opposition to the Pahlavi regime through extensive public demonstrations. During the regime's last months, the Zagros committee attempted to organize the public protests against the regime more effectively. However, neither the KDP nor any other Kurdish political organization was prepared enough to take advantage of the opportunities that the fall of the regime gave the Kurds. Hassanzade explicitly asserts that at the time of the regime's fall, the KDP was simply unable to act in a way that would have promoted Kurdish interests in any new arrangement following the revolution. ${ }^{17}$

\section{THE ISLAMIC REPUBLIC OF IRAN AND THE KURDISH AGENDA}

The Islamic Revolution put an end to the longstanding exile of the KDP, and the party leaders were hopeful and optimistic of starting a new period as a legal political party. Only three weeks after the Revolution, the KDP celebrated the end of its clandestine life and a new period of legal and public activities in Iranian Kurdistan by organizing a rally in Mahabad. About 100,000-150,000 people took part in the rally, as Dr. Qasimlu declared that his party was ready to cooperate with the new regime if the rights of the Kurds were guaranteed. ${ }^{18}$

Contrary to the rest of Iran, where the new provisional government had been able to establish its new structures, Kurdistan was under the hegemony of the KDP and revolutionary committees that were not in any way associated with the new government and its Islamist doctrine. ${ }^{19}$ While the Kurds were generally positive towards the new regime, and tried to convince the Iranian authorities to accept the democratic rights of the Kurds, it was a situation that was not to last. Tensions were readily apparent when, on February 19, 1979, the military garrison in Mahabad, largely due to the influence of some Kurdish officers, surrendered to the Kurdish authorities in the city. The Iranian regime used this occasion as a pretense to accuse the Kurds of acting against the

17. Hassanzade, Niw Sada Tekoshan, p. 123.

18. Hassanzade, Niw Sada Tekoshan, p. 259.

19. The influential political actors in Kurdistan during this period were the KDPI, Komala, the Organization of Iranian People Fadayee Guerrillas, Sheikh Ezaddin Hosseini, and Ahmad Moftizade. 
revolution. In an attempt to ease tensions, some Kurdish delegations visited the Iranian authorities, including Ayatollah Ruhollah Khomeini. However, no agreement was ever reached and as a consequence of the failed negotiations the tension escalated into armed confrontation. ${ }^{20}$

But the new government was simply not strong enough to control the Kurdish cities. The Kurds' activism and their practical control of most parts of Iranian Kurdistan made it difficult to quell the Kurds and ignore their demands. Nevertheless, there was no sign that the government was interested in finding a peaceful solution. In fact, it seems to be clear that the new theocratic government did not have an understanding of the particular ethnic issues which characterized their multi-ethnic country, and the conflict quickly escalated. Only five weeks after the revolution, during the Newroz celebrations, a bloody military assault was undertaken against Sanandaj, one of the major Kurdish cities in Kurdistan. In this confrontation, which is now known as the Bloody Newroz of Sanandaj, about 450 people were killed. ${ }^{21}$

The first official Kurdish challenge to the new government came about two months after the revolution when, on April 1, 1979, a referendum was held in Iran concerning the form and name of the new government. ${ }^{22}$ Ballots gave the Iranians the sole options of saying simply "yes" or "no" to "The Islamic Republic." The Kurds, following the position taken by their main political parties, boycotted the referendum. Despite this, the "Islamic Republic" was approved by a landslide. Even so, while the Kurds were quantitatively far from being able to hamper the project of the government and its referendum, they remained numerous enough to present a localized threat to the fledgling regime.

Realizing the futility of boycotts, the Kurds took part in the election of the Assembly of Experts on August 18, 1979. This council had the responsibility of writing the new constitution. The General Secretary of the KDP, Dr. Qasimlu, with 113,773 votes, was elected to be a member of the council. However, he was never able to participate. ${ }^{23}$ The council started its work on August 19, 1979, on the same day that Khomeini declared jihad against the Kurds, apparently to invigorate the Iranian force's efforts against the Kurds. The war came to an end on November 17, 1979, following rising casualties among Iranian military units. Kurdish guerrillas regained control over Kurdish cities, and in a public meeting in Mahabad, Dr. Qasimlu welcomed Khomeini's August 17, 1979 declaration of solving the Kurdish question peacefully. Soon after, a

20. After the revolution, the Kurds practically controlled Kurdistan. The new Iranian regime did not have any significant social or political influence over the Kurds. The presence of the regime was limited to its military garrisons in the main Kurdish cities. It took about three years until the Iranian regime gradually, through heavy military intervention, was able to establish its control over the Kurdish areas.

21. Hassanzade, Niw Sada Tekoshan, p. 140.

22. It is important to point out that this was the very day that the founders of the Kurdistan Republic were hanged in Mahabad in 1947. The Kurdish political parties even boycotted the national referendum on the Constitution of the Islamic Republic on December 2-3, 1979. This was a further contribution to the deepening of the conflict between the regime and the Kurds.

23. A few weeks after the election of the Assembly of the Experts, the elected members visited Khomeini, who explicitly said: "I wished he had come to this meeting. I had thought to arrest him if he had come." Hassanzade, Niw Sada Tekoshan, p. 161. 
Kurdish delegation consisting of Ezzaddin Hoseini, the KDP, Komala, ${ }^{24}$ and the Iranian People's Fadayee Guerrillas was created with the purpose of negotiating with the government. The delegation prepared a proposal which consisted of 26 articles that formulated the demands of the Kurds towards fulfilling the question of their autonomy. The main demands focused upon education in Kurdish, the establishment of local Kurdish security forces, and the appointment of local Kurdish administrators. Despite the occasional meeting between the Kurdish delegation and the various Iranian representatives, no agreement was reached.

Although a solution to the Kurdish issue in Iran was not found, it provided the Kurdish political actors space and time in which to consolidate their parties and militias. While irregular negotiations were ongoing, the Kurdish political parties were strengthening their political and social bases. It was in this environment that the KDP organized its fourth congress on February 19, 1980 in Mahabad. After 34 years it was the first time that the KDP could freely hold its congress in Iranian Kurdistan. Three hundred and ten delegates, who represented about 30,000 members of the KDP, participated. ${ }^{25}$

\section{FROM ELECTIONS TO REBELLION}

The Kurds took part in the election of the Iranian Parliament on March 14, 1980, with the vast majorities of candidates elected from Iranian Kurdish cities being members of the Kurdish political parties. However, the Iranian regime soon declared that the results from the Kurdish cities were void, and the elected candidates were never allowed to attend Parliament. ${ }^{26}$ During the summer of 1980, regular clashes broke out between the Kurds and government forces. However, the Kurds still had control over most parts of Kurdistan, including the cities. Until the late 1980s, there were still occasional negotiations between the Kurds, and especially the KDP, and the Iranian authorities. When Iraq invaded Iran on September 22, 1980, there were severe clashes between the Kurds and government forces. ${ }^{27}$ The KDP declared that if the government accepted the demands of the Kurds for autonomy, the Kurds would fight alongside Iran against

24. Komalay Shorshgeri Zahmatkeshani Kurdistani Eran (The Revolutionary Organization of the Toilers of the Iranian Kurdistan) declared its public presence as a radical leftist organization a few days after the revolution. Komala was formed in 1969 by Kurdish university students. In 1983 Komala - together with a number of Iranian leftist groups - founded the Iranian Communist Party (ICP), and Komala was afterwards referred to as the Kurdistan organization of the ICP. For a detailed account of the formation of Komala see Hossein Moradbeigi, Tarikhe Zende: Kordestan, Chap o Nasyonalizm [The Live History: Kurdistan, Left and Nationalism] (Nasim, 2004).

25. According to the statement of the fourth congress of the KDP in 1980, the party had 30,000 members. The number of party representatives in the congress was 310. Gadani, Penja Sal Khabat: Kurte Mejuyaki Hizibi, p. 228. According to Hassanzade, the number of party members at that time was 60,000. Hassanzade, Niw Sada Tekoshan, p. 206.

26. The regime could not accept the elected candidates. The fact that the regime did not have any control over the electoral procedure, and the subsequent results, led to them being declared void. Following this, the Kurdish cities were occupied and the regime arranged another election in 1981, resulting in the election of its own favored candidates. This election was boycotted by the Kurdish political parties.

27. Iran deployed four of its seven military divisions in Kurdistan during the war with Iraq. Gadani, Penja Sal Khabat: Kurte Mejuyaki Hizibi, p. 255. 
Iraq. ${ }^{28}$ However, the Iranian government, ignoring the KDP, intensified its attacks on the Kurds more than ever.

By early 1981, the number of victims of the ongoing war was increasing dramatically. In a statement made by the KDP in 1981, it noted that more than 10,000 people, $80 \%$ of them children and the elderly, had been killed. ${ }^{29}$ In November 1981, Iranian troops managed to occupy Bukan, which had been the last city under the control of the Kurdish guerrillas, thereby assuring their control over all the major population centers in Kurdistan. However, the Kurdish guerrillas were still strong enough to hold most of the rural areas and could attack the bases of the regime's forces inside the cities. But the pressure of the Iranian forces on the Kurds gradually forced the Kurdish guerrillas to move towards the Iraqi border and, by 1983, their headquarters was relocated to Iraqi territory.

The internal conflicts between the various factions of the Iranian government resulted in the removal of the first elected President of Iran, Abolhassan Banisadr, in June 1981. In July 1982, the removed President and Masud Rajavi, the leader of the Organization of Iranian People's Mojahedin, declared the establishment of the National Council of Resistance in Paris. Soon after, the KDP joined the Council, which in 1983 declared its agreement with the idea of Kurdish autonomy in Iran. The fact that the KDP joined the Council of Resistance intensified the animosity of the Iranian government towards the Kurdish parties to an unprecedented level. However, the Council expelled the KDP from its organization in 1985 due to their reluctance to condemn any kind of negotiations with Tehran.

One of the factors that explained this reluctance to negotiate was the weakness of Kurdish resistance brought about by the disunity of the Kurdish parties. The 1980s were particularly problematic for the Kurds in this regard. During this period, the Iraqi Kurdish forces fighting against the Iraqi regime had their bases in Iran, in effect bringing into proxy conflict the Iranian-supported KDP and the Iraqi-supported Iranian KDP. ${ }^{30}$ Another fatal blow to the Kurdish movement in Iran was the civil war between the KDP and Komala that started in 1984. After the split in the KDP following its eighth congress in 1988, the newly emerged KDPI (Revolutionary Leadership) declared a unilateral ceasefire with Komala. However, the war between the KDPI and Komala went on a few years more. ${ }^{31}$ The split of the KDPI in 1988 following the eighth party congress divided the leadership of the party into two. ${ }^{32}$ Worse was to come. The end of the Iraq-Iran War on August 20, 1988 affected the already unbalanced equation

28. Hassanzade, Niw Sada Tekoshan, p. 259.

29. Gadani, Penja Sal Khabat: Kurte Mejuyaki Hizibi, p. 260.

30. The armed conflict between the two parties started in 1984 and continued throughout the rest of the decade. A faction of the KDP (the Revolutionary Leadership), after its split formed the KDPI in 1988, declared a ceasefire which was welcomed by Komala. Although no specific date was announced by the KDPI and Komala regarding the ceasefire, the armed conflict had practically ended by 1991. Since 1991 the two parties have had a friendly relationship. Hassanzade, Niw Sada Tekoshan, pp. 277-80.

31. For a detailed account of the war between Komala and the KDP see Ayyub Ayyubzade, Chap le rojhelati Kurdistan: Komala u dozi nasyonali Kurd [Left in Eastern Kurdistan: Komala and the Condition of Kurdish Nationalism], Vol. 1 (Nima Verlag, 2002). Although Ayyubzadeh provides a detailed account of the war between these parties, he fails to keep himself detached from the events, and his ideological opposition to Komala makes the objectivity of the book questionable.

32. After about ten yeas of acting as two different political parties, the factions finally reunited in 1997. In December 2006, another major split in the KDP had more or less the same factional basis. 
of power between the Iranian government and the Kurds. The assassination in Vienna of the KDPI's leader, Dr. Abd al-Rahman Qasimlu, less than a year after the end of the war on July 13, 1989, showed the determination of the government to silence any opposition to its authority. Qasimlu's assassination, followed only three years later by the assassination of his successor Dr. Sadiq Sharafkandi in Berlin on September 17, 1992, dealt a heavy blow to the KDPI.

\section{OPPORTUNITIES AND CONSTRAINTS FOLLOWING THE 1990-91 GULF WAR}

The consequences of the Gulf War in 1990 further changed the political conditions in the region. The establishment of the Kurdistan Regional Government (KRG) in Iraqi Kurdistan in 1991 altered the earlier presuppositions of the Iranian Kurds who had stayed in Iraqi Kurdistan. The relationship between the KRG and Iran could not tolerate any armed struggle against Iran by the Iranian Kurds. Practically, the possibilities of an incursion inside Iranian borders had been ended and both the Iranian KDP and Komala were prevented from military acts against Iran. However, the Iranian regime still managed to assassinate numerous Iranian Kurds based in KRG-controlled Iraq. Some sources estimate that the number of Iranian Kurds who were murdered by Iranian agents in Iraqi Kurdistan during the early 1990s exceeded $200 .^{33}$

Meanwhile, social and political changes were taking place in Iran, as exemplified by the election of Muhammad Khatami as President of Iran in 1996. During Khatami's time in office, his policies opened up cultural and political space to a degree not previously witnessed in the Islamic Republic. The Iranian Kurds, inspired by the achievements of the Iraqi Kurds and the escalation of the PKK's activities in Turkey, used this freedom and began to promote unprecedented cultural activities. Numerous Kurdish journals were published in Iranian universities and, in almost all Kurdish cities, literary and cultural societies were organized. The Kurdish members of the Iranian Parliament consolidated themselves into a single faction, and some new young Kurdish activists took part in political and social debates. Kurdish cultural delegations visited Iraqi Kurdistan and published their books and articles there, and the increased number of Kurdish students at Iranian universities and their active participation in various cultural activities showed the arrival of a new generation which displayed a high degree of political and national consciousness. Iranian Kurds followed Kurdish satellite TV channels, and these contributed to the formation of a new nationalist discourse. But, importantly, the published journals and books in Iranian Kurdistan showed a considerable difference from the discourse of the Kurdish parties, indicating that the old established parties of the KDP and Komala were beginning to lose their popularity among the new generation of politically-minded Kurds. ${ }^{34}$

33. Jalil Gadani, Penja Sal Khabat [Fifty Years of Struggle] Vol. 2 (Hiwa, Raniya, 2004), pp. 273-77. Hassanzade provides a detailed account of the shelling during the early 1990s. Abdullah Hassanzade, Niw Sada Tekoshan [Half a Century Struggle], $3^{\text {rd }}$ edition (Komisyoni chapamani hizbi demokrati kwrdistani Eran, 2002), pp. 306-16. Since the late summer of 2007 Iran occasionally has shelled the border areas around Qandil Mountain while pursuing the fighters of PJAK.

34. During the years of Khatami's presidency (1997-2005), there were many journals and newspapers published by Kurdish students in various Iranian universities. The stylistic and thematic features of these journals and magazines were quite different from the traditional discourse of the Kurdish 


\section{FROM REFORM TO REACTION}

The failure of Khatami to implement his reformist plans and the election of Mahmud Ahmadinejad as the Iranian President in 2005 signified another rough period for the Kurds. ${ }^{35}$ At the time that Ahmadinejad was about to start his term of office, the Kurdish cities witnessed a popular riot against the government. On July 9, 2005, Iranian forces killed a young Kurdish activist, Shwane Seyyed Qadir, in Mahabad. The news of Shwane's murder and the publication of photos of his tortured and lynched body caused an uproar among the people of Mahabad and prompted demonstrations in other Kurdish cities. The security forces brutally suppressed the demonstrations and killed at least 20 people, with hundreds of demonstrators arrested and interrogated. The policy of banning Kurdish newspapers and imprisoning Kurdish activists has remained a common occurrence during Ahmadinejad's presidency. ${ }^{36}$

During this period of activity, cultural vibrancy, and repression in Iran, the Iranian Kurdish parties had remained removed from and out of touch in Iraqi Kurdistan. Seemingly in decline, they suddenly became reinvigorated when US policy began to take a clear stance against Iraq and Iran, with President George W. Bush identifying an "axis of evil" which included North Korea, Iraq, and Iran. With the US invasion of Iraq and the removal of Saddam Husayn from power, the Iranian Kurdish leadership in Iraq began to believe that, soon, Iran's leadership would be deposed and they would be at the forefront of "regime change," as their brethren had been in Iraq. However, the events after the collapse of Saddam's regime and the difficulties that the Americans faced in Iraq led to the fading of this hope. While the US has increased its contacts with representatives of the KDPI and Komala, as shown by a visit paid to the US by high ranking members of both parties in 2006, it remains the case that there seems to be no US policy against Iran that includes the resuscitation of the Iranian Kurdish parties. ${ }^{37}$

\section{[Continued from Previous Page]}

political parties. Many of the articles were of a strongly theoretical nature, engaging with Western literature and developments in philosophy and the social sciences. At the same time, there were many Kurdish novels published both in Iran and in Iraqi Kurdistan that were authored by Kurds from Iran. For this generation of students, academics, and writers, the political parties had little if any influence over their intellectual development or activities.

35. It is important to note that in the presidential election that resulted in Ahmadinejad's election the rate of participation in the Kurdish cities was the lowest: 9\% in Mahabd, 11\% in Bukan, 20\% in Sanandaj, and 15\% in Mariwan. See www.dw-world.de/popup_printcontent/0,3118311,00.html.

36. During the last three years many Kurdish journals and newspapers, such as Rojhelat, Aso, Ashti, and Peyami Kurdistan, have been banned.

37. For an account of Mohtadi's view on the American policy towards Iran and his own expectations from the US, see Michael J. Totten's exclusive report and interview with the leaders of Komala published in "The next Iranian revolution: how armed exiles are working to topple Tehran's Islamic government," Reason, October 2007, http://findarticles.com/p/articles/mi_m1568/is_5_39/ ai_n21053007. In an interview with The New York Sun, Mohtadi complained about American policy toward the Kurds in Iran and asserted that he still did not know what the American strategy was concerning the Iranian regime. See Eli Lake, "Kurdish Iranian Opposition Leader Seeks Clear Strategy from U.S.," The New York Sun, May 18, 2007, http://www.nysun.com/article/54773. Mustafa Hijri, the General Secretary of the KDPI, asserted that his party had a political relationship with the US. However, he believed that the US did not have a clear strategy regarding the Iranian regime. See http://www.sbeiy.com/ku/Inter_Report_Detail.aspx?id=78\&cat=2, March 31, 2008. 
The increasingly prolonged exile of the Iranian Kurdish political parties in Iraqi Kurdistan has resulted in more crises in their organization. ${ }^{38}$ It is not accidental that there have been major splits in both the KDPI and Komala during recent years. In December 2006 a significant number of KDPI members declared themselves to be simply "the" KDP (with "Iran" omitted from the name of the party) and claimed that democratic principles had been neglected by the majority of the KDPI's politburo. ${ }^{39}$ In October 2007, Komala split and a number of its leading figures, accusing the politburo of Komala of being non-democratic, announced the formation of a new organization, "Komala-the faction of reform," which later changed its name to Komalay Zahmatkeshani Kurdistan (The Organization of the Toilers of Kurdistan). ${ }^{40}$ In both cases, the solution to disagreements among the factions was far from democratic and on many occasions turned violent. If it was not for the KRG's interference these conflicts easily could have escalated and it was only through the interference of Iraqi Kurdish leaders that the factions were able to solve their — largely financial — disputes with each other.

\section{THE POWER OF SATELLITE TV}

During the last several years a new phenomenon has colored Iranian Kurdish

38. The KDPI only has two years of public and legal presence in Iranian Kurdistan. In other words, the party has been obliged to carry on its activities clandestinely. Hassanzade, Niw Sada Tekoshan, p. 6.

39. Following the $13^{\text {th }}$ congress of the KDPI, the conflict in the leadership of the party accelerated and a number of the members of the central committee of the party declared the formation of a new party. In March 2008 this new faction arranged its $14^{\text {th }}$ congress, in Koya in Iraqi Kurdistan. Kalid Azizi, who had been living in Sweden since the mid-1980s, was elected as Spokesman of the party. See http://www.Kurdistanukurd.com/kurdi/news.php?extend.172. In September 2009, his title was changed to General Secretary.

40. Komala had experienced other splits earlier. In 1991 the main figure of the ICP, Mansur Hekmat, alongside a major group of the leaders and cadres of the ICP resigned from the party and founded the Worker Communist Party of Iran. There have been at least four major splits in the WCPI during recent years. The Iranian Communist Party also has been subject to a range of splits. Some of the leaders of the ICP, under the leadership of Abdullah Mohtadi, split from the party in 2000 and reorganized the older Komala, i.e., the Revolutionary Organization of the Toilers of the Iranian Kurdistan. There are now five organizations that are active under the same name of Komala: 1) The Kurdistan Organization of the Iranian Communist Party-Komalah (note the "h" at the end of the name, apparently influenced by the Persian pronunciation of the name) under the leadership of Ibrahim Alizadeh; 2) The Revolutionary Organization of Toilers of Iranian Kurdistan, under the leadership of Abdulla Mohtadi. In the $12^{\text {th }}$ congress of Komala in August 2007, Komala modified its name in Persian to Hezb-e Komala-ye Kordestan-e Iran (Komala Party of Iranian Kurdistan); the Kurdish version remained unchanged. See http://www.komala.org/farsi/asnad/konge12/071003Asasnameh.pdf; 3) The Organization of Toilers of Kurdistan, led by Omar Ilkhanizade; 4) Komalay Shorshgeri Zahmatkeshani Kurdistani Eran - Rewti Yekgrtnewe (The Revolutionary Organization of Toilers of Iranian Kurdistan - Reunification Faction), led by Abdulla Konaposhi. This faction split to form Mohtadi's Komala on April 29, 2008, accusing Abdullah Mohtadi of non-democratic management of Komala and a policy of cooperation with Reza Pahlavi and the monarchists in Iran. See http://www.komalaorg.org/Direje_K.aspx?Cor=Rageyandin\&Jimare=23; 5) On July 15, 2009 a group of ICP cadres announced that they, following their split from the ICP, would work as Rewti Sosialisti Komala (Socialist Faction of Komala). See http://www.4rojhelat.org/files/print.php/2009/07/16/2510-2.phtml. 
politics. Previously, the Kurdish parties reached the public through their limited radio programs that broadcast from stations based in Iraqi Kurdistan. Now, the arrival of digital satellite TV broadcasting has revolutionized the parties' abilities to communicate with their public. ${ }^{41}$ Although the Kurdish parties' use of satellite TV goes back to 1995 when the first Kurdish satellite TV station was established in Europe, it was only in 2006 that Iranian Kurdish parties could start using such an influential medium. Today, most of the parties have access to their own satellite TV stations based on Europe: Tishk TV (the "sun-ray"), based in Paris, is the mouthpiece of the KDPI; the Kurd Channel, based in London, is the mouthpiece of the KDP; Rojhelat TV (East), based in Sweden and belonging to Komala (The Revolutionary Organization of the Toilers of Iranian Kurdistan); Komala TV, based in Sweden and belonging to Komala (the Kurdistan branch of the Iranian Communist Party); Newroz TV, based in Sweden, is the mouthpiece of Parti Jiyani Azadi Kurdistan (Free Life Party of Kurdistan, PJAK); and Aso Sat (Horizon), belonging to Komala's Faction of Reform, which later adapted its name to Komalay Zahmatkeshani Kurdistan (The Organization of the Toilers of Kurdistan). The programs broadcast from these TV stations are mostly political and aim to mobilize their Kurdish audience in Iran against the regime.

\section{THE RISE OF NEW PARTIES}

During the 1980s and 1990s, the major Kurdish political parties of Iranian Kurdistan were the KDPI and Komala. However, since the early 1980s, other Kurdish political parties have been established. On June 21, 1980 the Sunni "Organization of National and Islamic Struggle" was formed by a group of religious and civil activists who were earlier active in Ezaddin Hosseini's office. The main figure of this organization was Ezaddin Hosseini's brother, Shaykh Jalal Hosseini, who was the Imam in Bane in Iranian Kurdistan. The organization split in 1987, with the current leadership accusing their opponents of being influenced by agents of the government. In its third congress in 2006 the organization changed its name to the "Organization of Struggle of Iranian Kurdistan," under the leadership of Sheikh Jalal's son, Babeshekh Hosseini. The organization strives for Kurdish autonomy in Iran, while employing Islam as one of the main sources of legislation. The organization publishes a journal, Tekoshan (Struggle), as its main propaganda outlet. ${ }^{42}$

In May 1991, the Revolutionaries' Union of Kurdistan was established in Iraqi Kurdistan. The founder of this organization, Said Yazdanpanah, was a former member of the Iranian Fadayee Guerrillas' organization. After the assassination of the founder of the organization in September 1991 in Sulaymaniya in Iraqi Kurdistan, his brother, Hussein Yazdanpanah, led the organization. It declared its aims to be Kurdish selfdetermination, democracy, and socialism. On October 10-12, 2006, in a congress in Irbil in Iraqi Kurdistan, the organization changed its name to the Parti Azadi Kurdistan (Kurdistan Freedom Party, otherwise known as PAK) and elected Ali Qazi, the son of

41. The KDPI established its radio station, the Voice of Iranian Kurdistan, in August 1980. Due to security problems the station had moved 15 times by 1995. Hassanzade, Niw Sada Tekoshan, p. 250. Soon after the KDP, Komala also founded its own radio station.

42. Information is based on the organization's website, http://www.khabatmedia.com. 
Qazi Mohammad, as its leader and Hussein Yazdanpanah as Vice President. The new party announced the establishment of the Republic of Kurdistan as its main aim. ${ }^{43}$ On July 7, 2007 a group of the PAK's members, including Simko Yazdanpanah, Hussein's brother, split from the party and on August 12 declared the reorganization of the Revolutionaries' Union of Kurdistan. The new organization has the independence of Iranian Kurdistan as a component of its agenda. The organization elected Amine Khanim (the mother of Simko and Hussein) as its leader and Simko Yazdanpanah as its SecretaryGeneral. $^{44}$

\section{THE PKK LINK}

During the 1990s, when the established Kurdish parties were mainly absent in the ongoing political and cultural activities in Iranian Kurdistan, some Kurdish activists saw the Kurdistan Workers' Party (PKK) as an organization which could facilitate their revolutionary aspirations. In the early 2000s, the PKK, following structural and ideological changes in its organization, decided to organize its members based on their origin in various parts of Kurdistan into independent political parties. Parti Jiyani Azadi Kurdistan (Free Life Party of Kurdistan, PJAK), which was officially declared in 2004, was the product of this policy. ${ }^{45}$ The established Kurdish parties viewed PJAK with suspicion and, although unofficially, accused it of being the creation of the Iranian regime and, in the ongoing debates on building a Kurdish front, most of the Kurdish parties excluded PJAK from their plans.

On the other hand, the Iranian regime accused PJAK of being the agents of the US and Israel. This posturing against PJAK exemplified the concern that surrounded the ability of PJAK to upset the pattern of Kurdish-Iranian relations. Indeed, PJAK quickly showed that its ability to organize social and cultural activities while also carrying out armed struggle against the regime's bases within Iran's borders was significant. For many observers, these abilities indicate the support of external powers. When asked about this, Rahman Hajiahmadi (the leader of PJAK) enigmatically answered that his party was ready to establish relations with whomever wanted to support the Kurds and their struggle for freedom. ${ }^{46}$

\section{IRANIAN KURDS IN THE DIASPORA}

The tens of thousands diaspora Iranian Kurds who live in Europe also have been active in establishing political parties. By now three political parties have been estab-

43. http://www.pazadik.com/pages.php?pakid=11.

44. http://www.rukurdistan.com/index.php?id=46.

45. After the establishment of PJAK a group of its members left the party and went to Sulaymaniya in Iraqi Kurdistan. The group, which originally called itself "The Committee of Reorganizing PJAK" in a congress in Dukan in Iraqi Kurdistan in 2005, declared the formation of a new organization, Yaketiy Demokrati Kurdistan (The Democratic Union of Kurdistan). In the same year, some of the members of this group declared the formation of the "Kurdish Alliance," which was dissolved after only a few months. See http://www.dimane.com.

46. See Rahman Hajiahmadi's interview with Rojname on September 11, 2007, http://www.sbeiy. com/ku/Inter_Report_Detail.aspx?id=13\&cat=2\&title=2. 
lished in Europe, and all of them demand the establishment of an independent Iranian Kurdistan. In keeping with the disjointed picture of Iranian Kurdish political organization, these parties also have been borne out of internal argument and division. A former senior member of the KDPI, Amir Qazi, alongside a group of Kurdish activists, established the Parti Serbekhoyi Kurdistna (Kurdistan Independence Party) in 1989 in Sweden. In the third congress of the party in 1994 a group of its cadres and leading members left the party and later came together to form the Parti Serbestiy Kurdistan (Kurdistan Independent Party, PSK) ${ }^{47}$ on February 17, 2006. ${ }^{48}$ Aref Bawejani, who lives in Norway and was earlier a member of the KDPI, is leader of the party. Finally, Parti Sosialdemokrati Kurdistan - Rojhelat (Social Democratic Party of Kurdistan — East) was established in 2008 by a group of former members of Komala.

The Iranian Kurds also have been active in founding some non-ethnically focused political organizations inside Iran. In 2005 a group of Kurdish activists, including some of the members of the Iranian Parliament, founded Berey Yekgurtuy Kurd (Kurdish United Front) in Tehran. The Front aims for equal cultural, social, political, and economic rights for all Iranians. Though the front believes that some of the articles in the Iranian Constitution need to be revised, they believe that the correct implementation of the extant Constitution can contribute to the solution of Iran's ethnic issues. ${ }^{49}$ A group of Iranian Kurds also have been active in the Coalition of Kurdish Reformists, an umbrella organization formed during the 2009 election campaign. The Coalition was composed of nine political groups and associated with the various reformist organizations in Iran that had begun their activities during the presidential elections of $2005 .{ }^{50}$

\section{CONCLUSION}

The future of the Iranian Kurds is difficult to predict, as the variables that influence the situation are varied and mercurial. However, two dynamics can be readily identified as being durable, at least in the immediate period. These are the heavily fragmented character of the Kurdish political parties and the unwillingness of the Iranian regime to open a discourse focusing on the position of the Kurds, or any other ethnic minority, in the Iranian state. The result has been an increase in militancy in some parts of Iranian Kurdistan, as exemplified by the activities of PJAK. Yet the response from Iran has been uncompromising in its brutality and comprehensive in its coverage of Kurdistan. Faced with the might of the Iranian military, the limited military activities of the Iraqi-based Iranian Kurdish parties have resulted in many casualties and, without the support of the KRG, have been ineffective. ${ }^{51}$

47. See http://www.psk90.com/manifest.htm.

48. The translation of the name of both parties into English is the same. However, the Kurdish names of the parties are not identical, but rather are synonyms.

49. See http://www.kurduf.com/fa/shownews/news301002.aspx.

50. The coalition of the Kurdish reformists nominated its candidates for the eighth parliamentary elections in Iran in March 2008. However, 70\% of their candidates were disqualified and they were practically deprived of taking part in the election. See http://www.dw-world.de/dw/article/0,2144,3048803,00.html. Following the election, Hawar, the group's newspaper, was banned.

51. In August 2009, 11 Peshmarges from the KDPI, KDP, and Komalay Zehmetkeshani Kurdistan were killed in different parts of Iranian Kurdistan, following their penetration of Iranian borders. See http://www.kurdistanukurd.com/kurdi/news.php?extend.3676. 
The existing Kurdish political groupings such as the "Kurdish United Front" and "The Kurdish Reformists" inside Iran have shown that they are far from able to advocate for Kurdish rights successfully due to their weak voice and limited support. ${ }^{52}$ Indeed, the lack of a united Kurdish policy among the existing Iranian Kurdish political organizations has reduced their chances of affecting the political sphere in Iran in any meaningful way. ${ }^{53}$ Yet the fact that the Kurdish resistance against the Iranian government has been continuous since the early $20^{\text {th }}$ century shows that the Kurdish question in Iran only can be satisfied by a democratic solution which can provide the Kurds with their cultural and political rights. The continuity in the Kurdish resistance also shows that the policy of denial and oppression by Iranian governments is far from being effective. Just as in Iraq, the Kurdish factor in Iran can no longer be ignored, as the Kurds remain a significant but understudied actor in a state of critical importance.

52. The oppositional Kurdish political parties who mainly live in exile still have a certain degree of influence in Kurdistan. The Kurdish United Front and Kurdish reformists, due to the fact that they are new organizations and have neither the sufficient support of the government nor the Kurdish opposition parties, have not been able to develop popular support among the Kurds in Iran. One must add to this that the treatment of the Kurds in Iran by the government as a security issue denies them the opportunity to present their plans freely. This constitutes an important reason why these Kurdish political organizations inside Iran are weak.

53. Recently there have been some signs of cooperation among some of the Kurdish political organizations. In the tenth presidential election in Iran, which was held on June 12, 2009, the KDP, PAK, and PJAK did not boycott the election. The KDP and PAK, in a joint statement, implicitly supported the programs of Mehdi Karrubi, one of the presidential candidates. The other Kurdish political parties boycotted the election. Inside Kurdistan, the Kurdish United Front and the Kurdish reformists invited people to take part in the election and vote for Mehdi Karrubi and Mir Hossein Moussavi, who in their election manifestos were said to have explicitly promised to support the rights of Iranian ethnic minorities. 